\title{
Catabolism of Hydroxyproline in Vertebrates: Physiology, Evolution, Genetic Diseases and New siRNA Approach for Treatment
}

\author{
Ruth Belostotsky * and Yaacov Frishberg
}

Citation: Belostotsky, R.; Frishberg, Y. Catabolism of Hydroxyproline in Vertebrates: Physiology, Evolution, Genetic Diseases and New siRNA Approach for Treatment. Int. J. Mol. Sci. 2022, 23, 1005. https://doi.org/ $10.3390 /$ ijms 23021005

Academic Editors: Madhav Bhatia and Isao Ishii

Received: 22 December 2021

Accepted: 11 January 2022

Published: 17 January 2022

Publisher's Note: MDPI stays neutral with regard to jurisdictional claims in published maps and institutional affiliations.

Copyright: (C) 2022 by the authors. Licensee MDPI, Basel, Switzerland. This article is an open access article distributed under the terms and conditions of the Creative Commons Attribution (CC BY) license (https:// creativecommons.org/licenses/by/ $4.0 /)$.
Division of Pediatric Nephrology, Shaare Zedek Medical Center, Jerusalem 9103102, Israel; yaacovf@ekmd.huji.ac.il

* Correspondence: ruthb@szmc.org.il

\begin{abstract}
Hydroxyproline is one of the most prevalent amino acids in animal proteins. It is not a genetically encoded amino acid, but, rather, it is produced by the post-translational modification of proline in collagen, and a few other proteins, by prolyl hydroxylase enzymes. Although this posttranslational modification occurs in a limited number of proteins, its biological significance cannot be overestimated. Considering that hydroxyproline cannot be re-incorporated into pro-collagen during translation, it should be catabolized following protein degradation. A cascade of reactions leads to production of two deleterious intermediates: glyoxylate and hydrogen peroxide, which need to be immediately converted. As a result, the enzymes involved in hydroxyproline catabolism are located in specific compartments: mitochondria and peroxisomes. The particular distribution of catabolic enzymes in these compartments, in different species, depends on their dietary habits. Disturbances in hydroxyproline catabolism, due to genetic aberrations, may lead to a severe disease (primary hyperoxaluria), which often impairs kidney function. The basis of this condition is accumulation of glyoxylate and its conversion to oxalate. Since calcium oxalate is insoluble, children with this rare inherited disorder suffer from progressive kidney damage. This condition has been nearly incurable until recently, as significant advances in substrate reduction therapy using small interference RNA led to a breakthrough in primary hyperoxaluria type 1 treatment.
\end{abstract}

Keywords: hydroxyproline; primary hyperoxaluria; oxalate; glyoxylate; collagen post-translational modification; prolyl hydroxylase; HIF- $1 \alpha$; small interference RNA; protein compartmentalization

\section{Introduction}

Although proline (Pro) and hydroxyproline (Hyp) are often referred to as an amino acids, their correct definitions are imino acids, because they contain a secondary amino group (imine) in the pyrrolidine ring structure. This distinguishes Pro from all other genetically encoded (proteinogenic) open-chain amino acids. Hyp is formed by hydroxylation of Pro residues in the polypeptide chain. The vast majority of these post-translational modifications occur in procollagen, and they are critical for proper assembly and stability of mature collagen. Collagens are the most abundant proteins, accounting for about a third of all proteins in the body, while Hyp accounts for $10 \%$ to $15 \%$ of all its amino acid residues [1]. Another extremely important role of this modification is discrimination between normoxic and hypoxic conditions by oxygen sensitive hydroxylation of Pro in hypoxia-inducible transcription factor $(\mathrm{HIF}-1 \alpha)$ and some other related proteins. Hydroxylation of a Pro residue is an irreversible modification. Hyp is not a proteinogenic amino acid, and it cannot be re-incorporated into newly synthesized proteins, therefore, degradation of Hyp-containing proteins replenishes the Hyp pool for further metabolism. This process mainly takes place in the liver and, to some extent, in the kidneys. Considering the huge turnover of collagen, Hyp catabolism is essential for body homeostasis [2]. Hydroxylation of L-proline occurs in either the 3- or 4-position [3,4], and the catabolic pathways of these two derivatives are 
different. In humans, 4-Hyp, which accounts for about 99\% of Hyp, is converted stepwise to glyoxylate and glycolate in the mitochondria, and it finally turns into glycine in peroxisome [5]. Considering that glyoxylate can be oxidized to oxalate $(\mathrm{Ox})$ when accumulated in high concentrations, the metabolism of Hyp can potentially lead to the formation of this extremely harmful compound. Why is Ox production dangerous for the body? This is due to the low solubility of calcium oxalate $(\mathrm{CaOx})$ and the tendency of $\mathrm{CaOx}$ crystals to precipitate in the renal tubules following filtration. Massive $\mathrm{CaOx}$ depositions often impair kidney function and may lead to systemic oxalosis [6]. In healthy individuals, de novo production of Ox from Hyp occurs infrequently, and Hyp metabolism accounts for approximately one third of endogenous oxalate synthesis, the level of which itself is very low. [7]. Another source that contributes to oxalate synthesis is assimilation of glycolate from nutrition, especially plant food. Apparently, there are additional, yet unknown, precursors of this compound [8,9]. To avoid conversion of glyoxylate to Ox, it must be kept from interacting with lactate dehydrogenase (LDH) in the cytosol. This is achieved by separating the different stages of glyoxylate metabolism in closed cellular compartments (compartmentalization). Glyoxylate formation from 4-Hyp, and that from glycolate, was shown to occur in the mitochondria and peroxisomes, respectively. Thus, depending on which substrate is the main precursor of glyoxylate, alanine: glyoxylate aminotransferase (AGT), an enzyme that catalyzes the final step of 4-Hyp catabolism-the conversion of glyoxylate to glycine has distinct organelle distribution in species with diverse dietary habits [10]. It is localized in the mitochondria of carnivores, where the main contribution comes from dietary collagen degradation and the formation of Hyp. In herbivores, where the major source of glyoxylate comes from dietary glycolate, it is peroxisomal, while in omnivores it has dual localization. Disturbances in the glyoxylate pathway lead to the release or synthesis of glyoxylate into the cytosol and to Ox production catalyzed by LDH. Mutations in three genes encoding enzymes of glyoxylate metabolism lead to primary hyperoxaluria (PH1, 2, or 3), an early onset inherited kidney disease resulting in progressive kidney damage with wide phenotypic variability ranging from isolated kidney stone events to end stage kidney disease in infancy [11,12]. PH1 is the most severe condition, often leading to kidney failure. The only curative treatment for severe $\mathrm{PH} 1$ patients is combined liver-kidney transplantation, or, in rare cases, isolated liver transplantation, because oxalate overproduction takes place in the hepatocytes. Substrate reduction therapy (SRT) is considered a promising approach to design PH treatment based on depleting activity of one of the enzymes preceding glyoxylate production [13]. Tremendous success in the development of RNA interference (RNAi) technologies resulted in FDA and EMA approval of lumasiran as the first therapeutic agent for PH1 treatment in November 2020. In the phase 2 and 3 trials, the majority of patients who received lumasiran had normal or near-normal urinary Ox levels after 6 months of treatment $[14,15]$. SRT based on small molecule inhibitors and additional targets for RNAi, which can expand application to other forms of $\mathrm{PH}$, are currently under development [13].

\section{Posttranslational Modification of Proline Residue}

Hyp is the most abundant post-transnationally modified amino acid residue in animals. The major Hyp containing proteins are collagens, which are the structural proteins of the extracellular matrix. The tertiary structure of various types of fibril-forming collagen is shaped by a triple helix of polypeptide chains containing the repetitive Gly-X-Y motifs, whereas the $X$ and $Y$ positions can contain any amino acid, but mostly are occupied by Pro and 4-Hyp, respectively [4]. Hyp and Pro residues are critical for mechanical stability of collagens. Pro residues account for about $20 \%$ of all collagen amino acids, and about half of them are hydroxylated. In addition to collagens, several other proteins are reported to contain Hyp. In at least two of them, (elastin [16] and argonaute-2; Ago2 [17]), Pro hydroxylation increases their stability, while in the case of the HIF- $1 \alpha, \mathrm{O}_{2}$-dependent hydroxylation of Pro under normoxic conditions predisposes this protein to proteasomal degradation $[18,19]$. This is how the sensing of molecular oxygen is carried out. 
Pro residue is hydroxylated either at the 3- or at the 4-position by two enzyme families that reside in the lumen of the endoplasmic reticulum. These modifications take place prior to the formation of collagen triple helix. Hydroxylation occurs only on helical Pro residues, while Pro residues in the N-terminal and C-terminal telopeptides, which are not part of the Gly-X-Y motif, are not converted to Hyp [20]. This process requires additional substrates-2-oxoglutarate, molecular oxygen, ascorbic acid, and $\mathrm{Fe}^{2+}$ (Figure 1A).

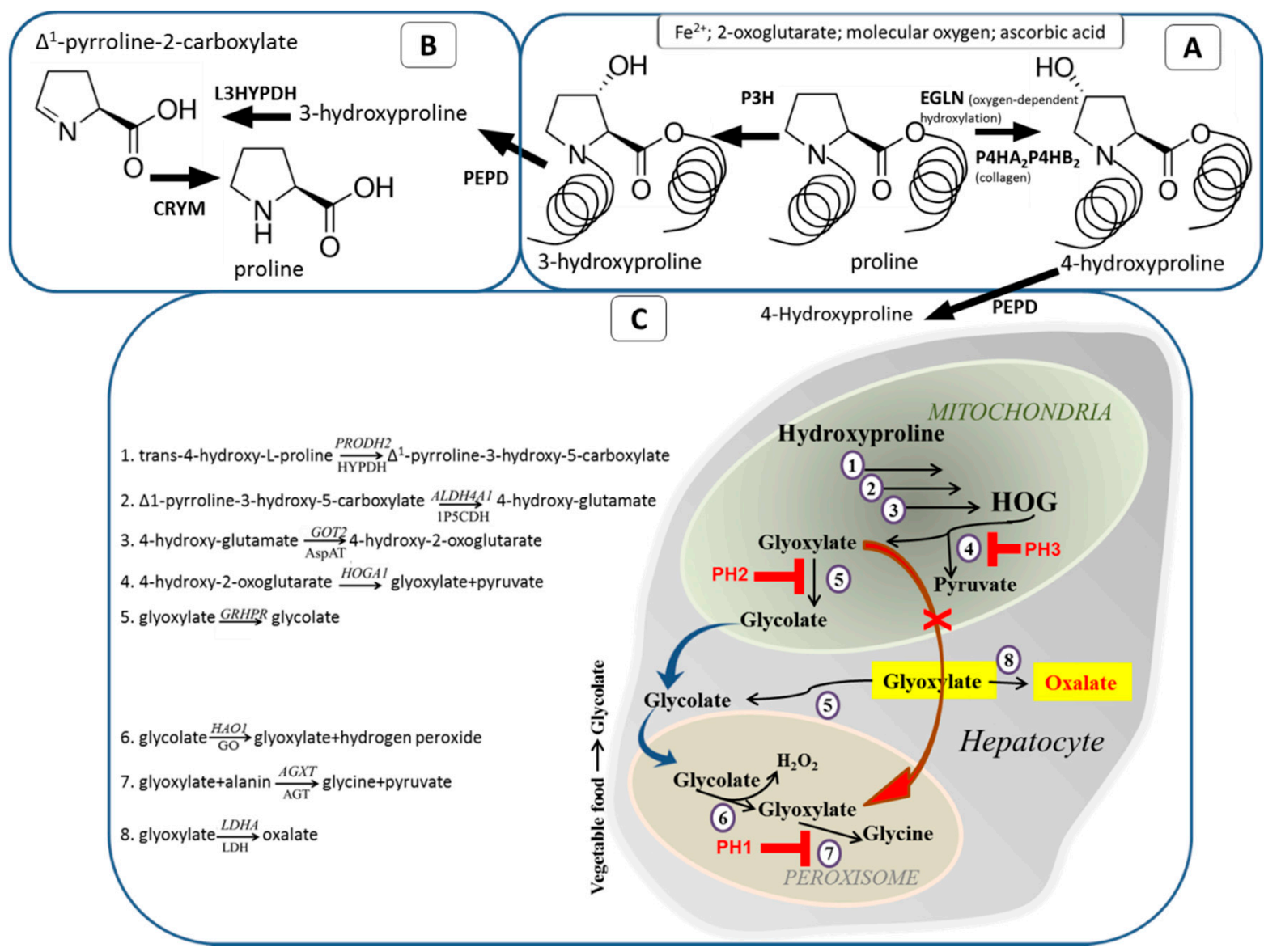

Figure 1. Schematic representation of proline hydroxylation (A), catabolism of 3-hydroxyproline (B), and 4-hydroxyproline (C). Gene designation in italic; protein designation (if different) in regular. $\mathrm{PH} 1, \mathrm{PH} 2, \mathrm{PH} 3-$ types of primary hyperoxaluria.

The vast majority of collagen modifications are at position 4 . This reaction is catalyzed by the enzyme prolyl 4-hydroxylase, composed of two alpha subunits (isoenzymes encoded by genes $P 4 H A 1,2$, or 3 ) and two beta subunits (encoded by $P 4 H B$ ) [20]. While the alpha subunit of prolyl 4-hydroxylase promotes substrate recognition and performs enzymatic activity, its beta subunit is responsible for retention of the tetramer in the endoplasmic reticulum. Unlike other prolyl 4-hydroxylase family proteins, P4HB possesses chaperon activity, thiol oxidoreductase activity, and it is involved in thiol related signaling and Nox NADPH oxidase regulation [21,22]. However, these activities are probably not related to prolyl 4-hydroxylase function.

Hydroxylation at position 3 is rare and is mainly found in type I and type IV collagens, with an occurrence of 2 to 10 per 1000 amino acid residues of collagen. The 3-hydroxylation of Pro in the repeating tripeptide, resulting in Gly-3Нyp-4Нyp, is catalyzed by one of three isoenzymes of prolyl 3-hydroxylase (encoded by $\mathrm{P} 3 \mathrm{H1}$, 2, and 3) in association with the helper proteins CRTAP and Cyclophilin B (PPIB) [23-25]. Oxygen-dependent hydroxylation of HIF- $1 \alpha$ is performed by another class of prolyl 4-hydroxylases named EGLN1, 2, and 3 (PHD1, 2, and 3). The oxygen requirement for EGLN-catalyzed hydroxylation and 
degradation of HIF-1 $\alpha$ provides an efficient molecular oxygen sensing mechanism [18,26]. Indeed, EGLN has a relatively high $\mathrm{Km}$ for $\mathrm{O}_{2}$, which is slightly higher than atmospheric oxygen concentration [19]. Conversely, collagen prolyl hydroxylase P4HA has a low Km for oxygen, and its activity is not affected by moderate levels of hypoxia. Thus, the $\mathrm{O}_{2}$ concentration is a rate-limiting factor for EGLN enzymatic activity under physiological conditions, and a small change in the cellular $\mathrm{O}_{2}$ concentration is directly translated into the level of prolyl hydroxylation of HIF-1 $\alpha$. EGLN prolyl hydroxylases have additional targets, such as protein kinases AKT1 and DYRK1 [27,28], and Pro hydroxylation can regulate other important proteins related to cellular oxygen sensing and response, including IKK- $\beta$, NFKB1 and p53 [29,30].

\section{Role of Pro Hydroxylation in Proteins}

Proline hydroxylation plays diverse roles in modified proteins. These include an increase in mechanical stability, participation in protein-protein interactions, and regulation of cellular hypoxia response.

\subsection{Hyp in Collagen}

Collagens are a group of structural proteins that serve as a molecular scaffold, and these are expressed in connective tissues, providing their mechanical stability and shape. Collagens are deposited in the extracellular matrix, and they interact with cells through several families of receptors, mainly through integrins, dimeric discoidin receptors (DDR), and glycoprotein VI. These interactions lead to the regulation of cell differentiation, proliferation, adhesion, and migration. Currently, 28 vertebrate collagens are known; the expression of some types of collagen is limited to specific tissues, which allows for a variety of biological functions [31]. Collagen's unique properties-thermal and mechanical stability, and the ability to enter into specific interactions with other proteins-stem from its triple helical organization provided by the repeating Gly-X-Y motifs. Mature collagen, which is a left-hand helix of three polypeptide chains, is called tropocollagen. Several tropocollagen molecules may self-assemble to form fibrils or reticular structures. While the stability of this spiral rod, about $300 \mathrm{~nm}$ in length and $1.5 \mathrm{~nm}$ in diameter, is provided by the Gly-Pro-4-Hyp repeats, its flexibility is achieved by the presence of defects and breaks in this motif because regions poor in Pro and Hyp form triple helices that are more relaxed [32]. The pyrrolidine rings of Pro and 4-Hyp stabilize this structure, but 4-Hyp provides the additional thermal stability. The melting temperature of tropocollagens is directly proportional to the 4-Hyp content [4]. The existence of 4-Hyp is critical for the stability of the tropocollagen, but this is not fully understood. One of the considerations is that collagen is stabilized mainly by water molecules surrounding collagen that provide a formation of a network of hydrogen bonds between the hydroxyl group of 4-Hyp and main-chain's oxygens [33]. Another consideration is that 4-Hyp reduces the number of conformations available to the random coil of triple helix [34]. The latest update on the current understanding of this effect is summarized by Taga and colleagues [35].

Hyp plays an important role not only in contributing to the rigidity of collagens, but also in protein-protein interaction. Typical integrin recognition sites often contain 4-Hyp residues [36]. DDR-collagen interaction is also Hyp dependent, and substitution of 4-Hyp in Gly-Pro-4-Hyp repeat was shown to reduce DDR2 binding with collagen [37]. The involvement of 4-Hyp in interactions of collagen with glycoprotein VI is well established [38]. However, recently, it was demonstrated that 3-Hyp plays a major role in interactions of type IV collagen with glycoprotein VI [39]. 


\subsection{Role of Hyp in Oxygen-Sensing}

The discovery of the ubiquitous oxygen-sensing mechanism in mammalian cells, and the important role of Hyp in this process, culminated in the 2019 Nobel Prize in Medicine and Physiology being awarded to Greg Semenza, Peter Ratcliffe, and William Kaelin [40]. HIF is a transcription factor that activates the expression of hypoxia-induced genes in various cell types. HIF-activated genes are involved in erythropoiesis, angiogenesis, iron homeostasis, glucose uptake, and, finally, in the regulation of cell survival and apoptosis. Kaelin [19] and Ratcliffe [41] both demonstrated that enzymatic hydroxylation of Pro residues in normoxia results in ubiquitination of HIF- $1 \alpha$ by the von Hippel-Lindau tumor suppressor protein (VHL), followed by proteasome degradation of the transcription factor. The hydroxylated residues Pro-402 and Pro-564 are involved in VHL binding. In these conditions, the half-life of HIF-1 $\alpha$ is extremely short (less than $10 \mathrm{~min}$ ) [41]. Hypoxia prevents prolyl hydroxylation and degradation of HIF- $1 \alpha$, and it allows binding of the transcription factor to hypoxia response elements in the promoters of hundreds of genes involved in metabolic adaptation to low oxygen. Discovering the mechanism of HIF- $1 \alpha$ regulation provides new directions for the development of therapeutic agents that stabilize or inhibit HIF. Recent studies have demonstrated that the HIF prolyl hydroxylase inhibitor daprodustat is an effective therapeutic agent that stimulates erythropoiesis and increases hemoglobin level [42]. Additionally, HIF-1 $\alpha$ inhibitors may potentially serve as anti-cancer drugs, since hypoxia is a common feature of solid tumors.

\section{Collagen Degradation and Further Metabolism of Hyp}

Collagen breakdown is carried out by sequential cleavage into dipeptides by matrix metalloproteinases [43]. The terminal and rate limiting stage of collagen degradation is catalyzed by prolidase (PEPD) [44]. This enzyme specifically splits dipeptides with C-terminal Pro or Hyp.

Further Hyp utilization depends on the position of hydroxylation. Trans-3-hydroxyL-proline (3-Hyp) is thought to be re-converted to L-proline via a two-step pathway: dehydration by trans-3-hydroxy-L-proline dehydratase (L3HYPDH), resulting in the formation of $\Delta^{1}$-pyrroline-2-carboxylate [45], followed by Pyr2C-reductase (CRYM) activity [46] (Figure 1B). Conversion of trans-4-hydroxy-L-proline (4-Hyp) to glyoxylate is performed by four sequential reactions (Figures $1 C$ and 2) [47-49]. All these reactions are catalyzed by mitochondrial enzymes: proline dehydrogenase 2 (PRODH2 or HYPDH), delta-1-pyrroline5-carboxylate dehydrogenase (1P5CDH), glutamic-oxaloacetic transaminase 2 (AspAT), and 4-hydroxy-2-oxoglutarate aldolase (HOGA1). However, only two of these, HYPDH and HOGA, are unique for the Hyp pathway, and the remaining two are also involved in Pro metabolism [5]. The final reaction of Hyp metabolism, transamination of glyoxylate to glycine, is catalyzed by alanine-glyoxylate and serine-pyruvate aminotransferase (AGT) encoded by AGXT gene (Figures 1C and 2). Hyp is an important source of glycine synthesis in animals [50]. This explains the low levels of urinary Hyp excretion, despite large amount of Hyp generated, due to the turnover of tissue collagen and the breakdown of dietary animal protein [2]. 


\section{Catabolic pathway of 4-hydroxyproline}

IN HUMANS AND HERBIVORES

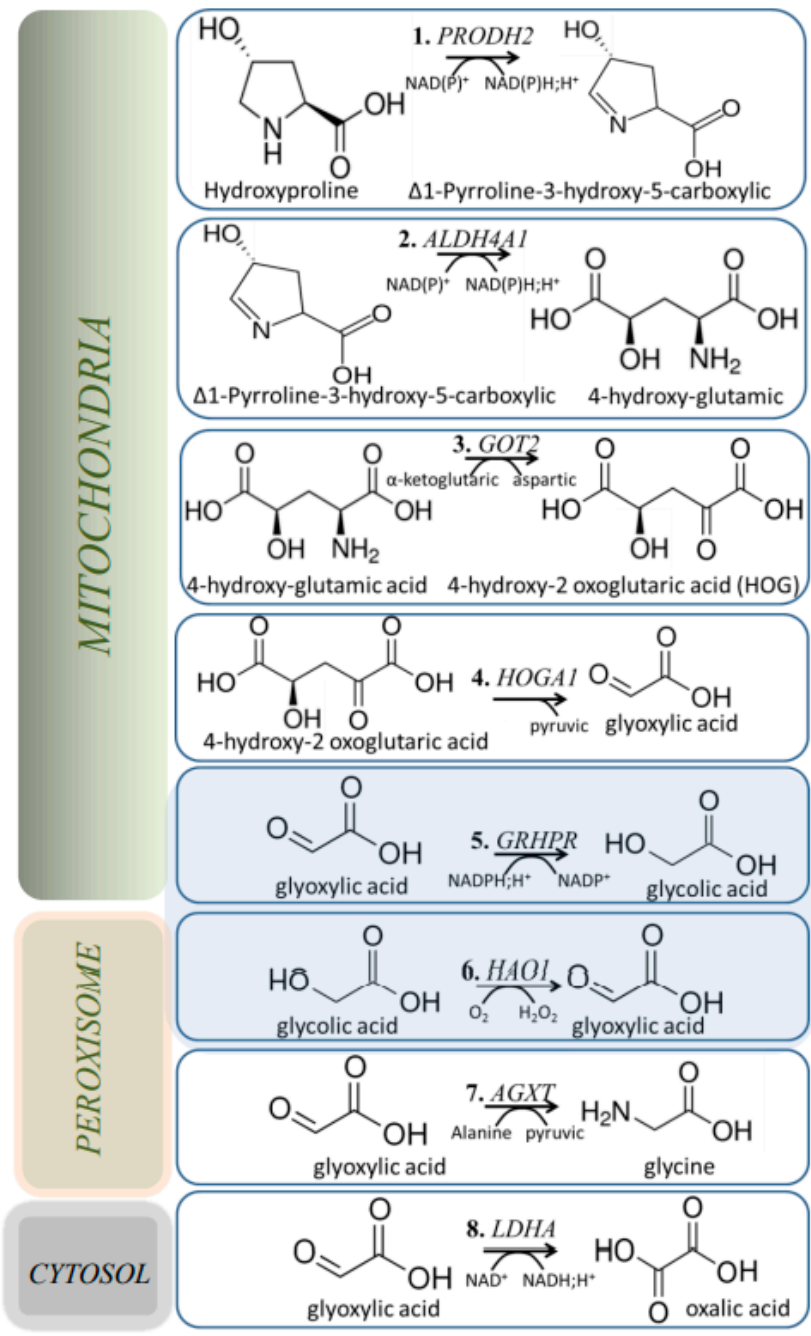

IN CARNIVORES

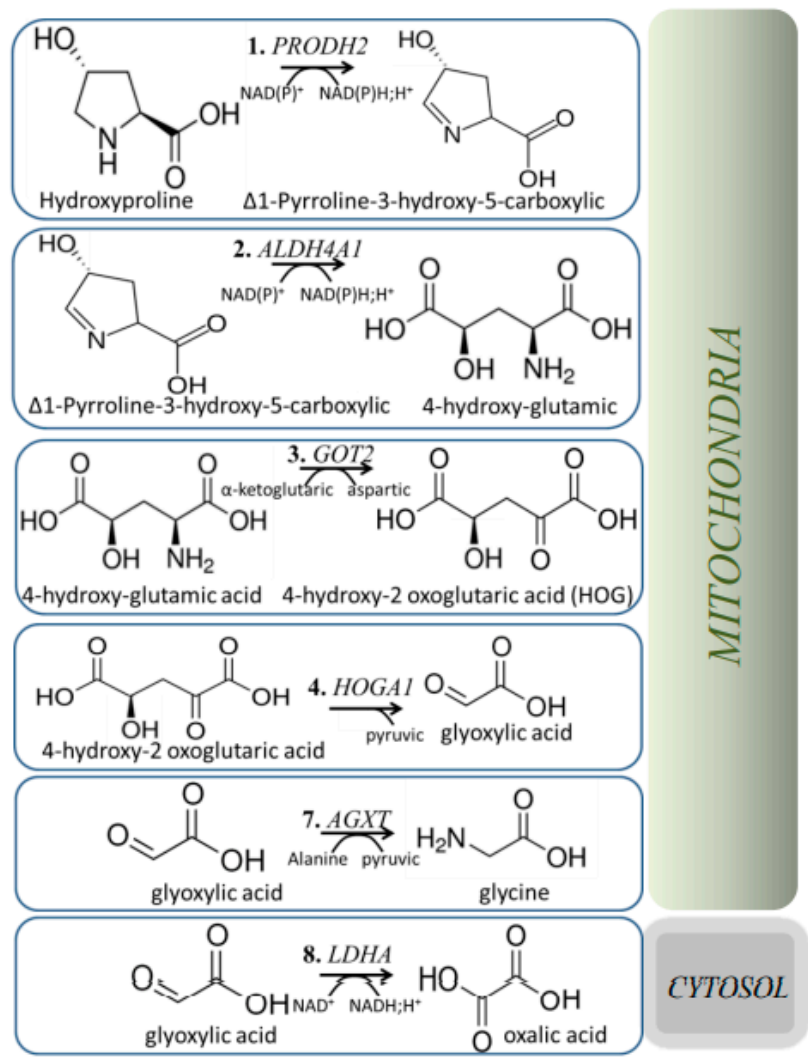

Figure 2. The catabolic pathway of 4-hydroxyproline in various vertebrate species.

\section{Evolutionary Aspects of Hyp/Glyoxylate Pathway}

Intracellular localization of AGT is species-specific-it is restricted in the mitochondria in carnivores and in the peroxisome in herbivores [10]. For some reason, in the case of peroxisomal AGT, the Hyp pathway is lengthened by two reciprocal reactions: reduction of glyoxylate to glycolate by mitochondrial glyoxylate reductase GRHPR, and oxidation of glycolate to glyoxylate by peroxisomal glycolate oxidase (encoded by HAO1) (Figure 2 in blue). How can such "wasteful" redundancy be explained? We proposed that these reciprocal reactions are needed in order to protect glyoxylate from exposure to cytosolic LDH during transportation to the peroxisome [51,52]. If cytosolic glyoxylate is the culprit, and mitochondrial AGT can efficiently convert glyoxylate to glycine, why is herbivorous glycolate not converted to glyoxylate by HAO1 inside the mitochondria? The need for a peroxisomal location of this reaction is because its co-product is a reactive oxygen species, hydrogen peroxide, and peroxisomes are the site where this harmful substance is neutralized [53]. Thus, the localization of HAO1 is invariant, whereas AGT can be located both in the mitochondria and the peroxisome. Indeed, studies conducted in Danpure's laboratory, and among other groups, showed significant correlation between intracellular AGT distribution and diet, independent of phylogeny of the organisms $[10,54,55]$. This is particularly impressive when analyzing such taxonomic units as bats, marsupials, and 
bears, where phylogenetically closely related species have different feeding patterns. Given that each species has only one AGXT gene, how does the structure of the gene in different species explain the different localization of the protein? It turns out that most $A G X T$ genes have the potential to encode an N-terminal mitochondrial targeting sequence (MTS) of 22 amino acids and atypical peroxisomal targeting tri-peptide (PTS1) at the C-terminal [56]. The presence or absence of MTS within the mRNA open reading frame, and the availability of this N-terminal signal, determines AGT mitochondrial compartmentalization, even in the presence of C-terminal PTS1 [10]. Expression of MTS, which abolishes PTS1 function, was investigated in bats [57], primates [58], and birds [59]. Bats that eat fish, insects, or blood possess intact MTSs. On the contrary, MTS is not included in the open reading frame in unrelated lineages of frugivorous bats [57]. Loss of MTS, among these species, was due to small deletions or insertions in the $5^{\prime}$ region, causing downstream stop codons or mutations in an initiation codon. Mitochondrial targeting could be regulated, not only by the loss of the upstream translation initiation ATG codon, but also by mutations changing the charge of MTS, because the transport of a protein into the mitochondria is directed by positively charged residues. For instance, MTS analysis of AGXT genes in primates demonstrated that, in a few branches, $5^{\prime}$ ancestral translation start site (ATG) has been lost, and, in one branch, a stop codon was generated inside the MTS. In other branches, substitutions reduced the number of basic residues or increased the amount of acidic residues in the $\mathrm{N}$-terminal sequence, which is expected to reduce the effectiveness of the MTS [58]. In omnivores, transcription or translation of $A G X T$ gene starts from two different in-frame sites [60]. Thus, it has been discovered that, although humans are omnivorous, the exclusively peroxisomal localization of AGT does not match this, and this probably makes the human body more prone to increased hepatic oxalate production. Indeed, derangements in hydroxyproline catabolism, due to genetic aberrations, lead to severe disease, namely primary hyperoxaluria.

\section{Primary Hyperoxaluria and Hydroxyprolinemia}

Primary hyperoxaluria results from excessive Ox production due to the concomitant activity of lactate dehydrogenase (LDH) (Figures $1 \mathrm{C}$ and 2). LDH is a cytosolic enzyme whose physiological function is to catalyze the reversible conversion of pyruvate to lactate using NADH. It provides substrates for the Cori cycle, which is a metabolic pathway by which lactate produced by anaerobic glycolysis in muscle is transported to the liver and kidney, and is converted back to glucose [61,62]. To avoid Ox production, glyoxylate synthesized in mitochondria or peroxisome must be further metabolized to glycine and kept from interacting with LDH in the cytosol. Disturbances in the glyoxylate pathway lead to the release or synthesis of glyoxylate in the cytosol, and to Ox production. Humans are able to handle low amounts of $\mathrm{Ox}$, however, its increase (hyperoxaluria) results in $\mathrm{CaOx}$ supersaturation in the urine leading to crystal formation. Loss of function of glyoxylate pathway enzymes is known to cause three types of primary hyperoxaluria. PH1 arises from insufficient activity of AGT, which is the enzyme that catalyzes the final step of the pathway that converts glyoxylate to glycine (Figure 2). Similarly, deficiency of PH2-related enzyme GRHPR, which catalyzes the reduction of glyoxylate to glycolate, results in the accumulation of glyoxylate in mitochondria followed by its release into the cytosol. On the contrary, glyoxylate is a product rather than a substrate of the third PH-related enzyme, 4-hydroxy-2-oxoglutarate aldolase (HOGA1) (Figure 2). The mechanism of Ox production associated with HOGA1 deficiency is a matter of debate $[52,63,64]$. We believe that, in the context of loss of function of HOGA1, its substrate 4-hydroxy-2-oxoglutarate (HOG) is accumulated in the mitochondria and released into the cytosol. Outside the mitochondria, the production of glyoxylate is performed by a cytosolic enzyme with nonspecific 4-hydroxy-2-oxoglutarate activity. This cytosolic aldolase has yet to be identified [52].

It should be mentioned that metabolic defect in the conversion 4-Hyp to $\Delta 1$-pyrroline5-carboxylate resulting in hydroxyprolinemia is considered a benign condition [65]. Hydroxyprolinemia usually results from HYPDH deficiency, however, identifying a patient 
with persistent hydroxyprolinemia, who failed to have mutations in HYPDH encoding gene, leaves the possibility of additional defects in hydroxyproline catabolism [66]. Deficiency of glycolate oxidase (HAO1), another enzyme in the glyoxylate pathway, results in asymptomatic isolated glycolic aciduria without any apparent related abnormalities $[67,68]$.

\section{PH Therapy}

Until recently, there were no approved treatments for primary hyperoxaluria that could prevent renal failure or significantly reduce other symptoms. The only exception is the use of pyridoxine, the precursor of pyridoxal phosphate, which is an essential cofactor of AGT, for the treatment of PH1 patients with mutations leading to mitochondrial mislocalization of AGT, mostly the p.Gly170Arg mutation [69,70]. Only liver transplantation corrects the underlying metabolic defect in PH1, and, further, in most cases, kidney transplantation is required along with liver transplantation. $\mathrm{PH} 1$ patients with compromised renal function or with kidney failure awaiting transplantation require up to six hemodialysis sessions per week [11,12].

New experimental approaches provide promising directions for PH drug development. Ox production represents cell-autonomous metabolic defect where activity-deficient hepatocytes overproduce oxalate, even once a large fraction of the mutant host hepatocytes have been corrected. This poses an additional challenge for the development of PH treatments. Substrate reduction therapy (SRT) is considered a promising approach to design PH treatments based on depleting the activity of one of the enzymes preceding glyoxylate production. Enzyme inactivation/inhibition can be achieved by the use of small molecules, RNA interference, or targeted genomic intervention. A promising candidate for SRT is the top enzyme of Hyp metabolism, HYPDH [5]. In theory, this therapy is suitable for all three types of PH. The same is true for LDH inhibition, which is not SRT but is also based on depleting enzymatic activity. However, the most popular SRT target is $\mathrm{HAO} 1$, which is relevant only for the most severe condition, PH1. Considering that isolated glycolic aciduria, resulting from HAO1 deficiency in humans is a benign condition, it is considered a safe therapeutic strategy $[67,68]$. siRNA is an attractive way to knockdown the expression of target proteins. As a result of the latest breakthrough in $\mathrm{PH}$ therapy being achieved through a revolutionary application of this approach [71], we will mainly discuss this methodology, whereas detailed information on the development of other drugs is summarized in recent reviews on this topic [13,72,73]. One of the advantages of applying RNA interference for the treatment of PHs is the possibility of targeted delivery of miRNA to hepatocytes, preventing off-target effects in other tissues. Conjugate-based delivery is designed utilizing N-acetylgalactosamine (GalNAc) ligands that bind to the asialoglycoprotein receptor (ASGPR) specifically expressed by hepatocytes. Subsequently, conjugated synthetic dsRNA, homologous in sequence to the silenced gene, is taken up by endocytosis via ASGPR, and then it escapes from the endosomes into the cytosol. siRNA is incorporated into an RNA-inducing silencing complex (RISC) where the duplex RNA is unwound leaving the anti-sense strand to guide RISC to complementary mRNA [74]. The silencing of the target template is catalyzed by cleaving the mRNA with the enzyme Ago2, which, incidentally, is a rare protein stabilized by prolyl 4-hydroxylation [17]. Lumasiran is a synthetic siRNA aimed to reduce the hepatic production of glycolate oxidase by degrading HAO1 mRNA. In phase 3 trials, lumasiran reduced urinary oxalate excretion in the majority of PH1 patients to normal or near-normal levels after 6 months of treatment $[14,15,75]$. It is administered subcutaneously in 3 monthly loading doses followed by quarterly doses as of the 4th month. In November 2020, Oxlumo (lumasiran) was approved for the treatment of patients with PH1 in all age groups by the FDA and the EMA.

Nedosiran is another hepatocytes' targeted siRNA that inhibits LDHA responsible for the final step of oxalate production. The advantage of this approach is that, theoretically, it may be suitable for all types of PH [76]. Pre-clinical experiments in a mouse model of $\mathrm{PH} 1$ and $\mathrm{PH} 2$ treated with LDHA-specific siRNA resulted in an efficient reduction of $\mathrm{CaOx}$ excretion while preventing crystal deposition in mouse kidneys [77]. The first phase of 
clinical trials of Nedosiran on $\mathrm{PH} 1$ and $\mathrm{PH} 2$ patients demonstrated a positive effect on Ox production $[78,79]$, however, in phase 2 trials, $\mathrm{PH} 2$ and $\mathrm{PH} 3$ patients did not achieve the primary endpoint of significant urinary oxalate lowering effect [80,81].

\section{Conclusions}

Hydroxyproline is a non-proteinogenic imino acid that provides important structural and regulatory properties to a limited number of proteins, including collagens, HIF, integrins, and Ago2. In this article, we have described why the post-translational hydroxylation of Pro in various protein substrates is carried out by different types of prolyl hydroxylases, and we have investigated the biological necessity of such modifications. Although only a few types of proteins undergo such modification, Hyp is one of the most common products of protein degradation. Collagen breakdown, and that of other hydroxylated proteins, must be accompanied by the metabolic processing of 4-Hyp, which converts this substance into glycine for further utilization. This pathway, which recruits numerous enzymes, can be complicated by the nonspecific formation of a dangerous compound, namely oxalate. We have discussed, in detail, the primary hyperoxaluria, which is a pathologic consequence of the defects of catabolism of Hyp, and we have described the essence of a new type of treatment for this disease based on innovative RNAi technology.

Author Contributions: Conceptualization, R.B. and Y.F.; writing-original draft preparation, R.B.; writing-review and editing, Y.F.; visualization, R.B.; funding acquisition, R.B. and Y.F. All authors have read and agreed to the published version of the manuscript.

Funding: This research was funded by Oxalosis and Hyperoxaluria Foundation.

Institutional Review Board Statement: Not applicable.

Informed Consent Statement: Not applicable.

Data Availability Statement: Not applicable.

Conflicts of Interest: The authors declare no conflict of interest.

\section{Abbreviations}

Pro, proline; Hyp, hydroxyproline; $\mathrm{Ox}$, oxalate; $\mathrm{CaOx}$, calcium oxalate; $\mathrm{PH}$, primary hyperoxaluria; SRT, substrate reduction therapy; RNAi, RNA interference; MTS, mitochondrial targeting sequence; PTS1, peroxisomal targeting signal 1; FDA, USA Food and Drug Administration; and EMA, European Medicines Agency.

\section{References}

1. Etherington, D.J.; Pugh, D.; Silver, I.A. Collagen degradation in an experimental inflammatory lesion: Studies on the role of the macrophage. Acta. Biol. Med. Ger. 1981, 40, 1625-1636.

2. McAnulty, R.J.; Laurent, G.J. Collagen synthesis and degradation in vivo. Evidence for rapid rates of collagen turnover with extensive degradation of newly synthesized collagen in tissues of the adult rat. Coll. Relat. Res. 1987, 7, 93-104. [CrossRef]

3. Gorres, K.L.; Raines, R.T. Prolyl 4-hydroxylase. Crit. Rev. Biochem. Mol. Biol. 2010, 45, 106-124. [CrossRef] [PubMed]

4. Rappu, P.; Salo, A.M.; Myllyharju, J.; Heino, J. Role of prolyl hydroxylation in the molecular interactions of collagens. Essays. Biochem. 2019, 63, 325-335. [PubMed]

5. Buchalski, B.; Wood, K.D.; Challa, A.; Fargue, S.; Holmes, R.P.; Lowther, W.T.; Knight, J. The effects of the inactivation of Hydroxyproline dehydrogenase on urinary oxalate and glycolate excretion in mouse models of primary hyperoxaluria. Biochim. Biophys. Acta Mol. Basis. Dis. 2020, 1866, 165633. [CrossRef] [PubMed]

6. Demoulin, N.; Aydin, S.; Gillion, V.; Morelle, J.; Jadoul, M. Pathophysiology and Management of Hyperoxaluria and Oxalate Nephropathy: A Review. Am. J. Kidney. Dis. 2021. [CrossRef]

7. Fargue, S.; Milliner, D.S.; Knight, J.; Olson, J.B.; Lowther, W.T.; Holmes, R.P. Hydroxyproline Metabolism and Oxalate Synthesis in Primary Hyperoxaluria. J. Am. Soc. Nephrol. 2018, 29, 1615-1623. [CrossRef] [PubMed]

8. Lange, J.N.; Wood, K.D.; Knight, J.; Assimos, D.G.; Holmes, R.P. Glyoxal formation and its role in endogenous oxalate synthesis. Adv. Urol. 2012, 2012, 819202. [CrossRef]

9. Li, X.; Fargue, S.; Challa, A.K.; Poore, W.; Knight, J.; Wood, K.D. Generation of a GLO-2 deficient mouse reveals its effects on liver carbonyl and glutathione levels. Biochem. Biophys. Rep. 2021, 28, 101138. [CrossRef] 
10. Oatey, P.B.; Lumb, M.J.; Danpure, C.J. Molecular basis of the variable mitochondrial and peroxisomal localisation of alanineglyoxylate aminotransferase. Eur. J. Biochem. 1996, 241, 374-385. [CrossRef]

11. Ben-Shalom, E.; Frishberg, Y. Primary hyperoxalurias: Diagnosis and treatment. Pediatr. Nephrol. 2015, 30, 1781-1791. [CrossRef]

12. Sas, D.J.; Harris, P.C.; Milliner, D.S. Recent advances in the identification and management of inherited hyperoxalurias. Urolithiasis 2019, 47, 79-89. [CrossRef]

13. Belostotsky, R.; Frishberg, Y. Novel therapeutic approaches for the primary hyperoxalurias. Pediatr. Nephrol. 2021, 36, 2593-2606. [CrossRef] [PubMed]

14. Frishberg, Y.; Deschênes, G.; Groothoff, J.W.; Hulton, S.A.; Magen, D.; Harambat, J.; Van't Hoff, W.G.; Lorch, U.; Milliner, D.S.; Lieske, J.C.; et al. Phase 1/2 Study of Lumasiran for Treatment of Primary Hyperoxaluria Type 1: A Placebo-Controlled Randomized Clinical Trial. Clin. J. Am. Soc. Nephrol. 2021, 16, 1025-1036. [CrossRef] [PubMed]

15. Garrelfs, S.F.; Frishberg, Y.; Hulton, S.A.; Koren, M.J.; O’Riordan, W.D.; Cochat, P.; Deschênes, G.; Shasha-Lavsky, H.; Saland, J.M.; Van't Hoff, W.G.; et al. Lumasiran, an RNAi Therapeutic for Primary Hyperoxaluria Type 1. N. Engl. J. Med. 2021, 384, 1216-1226. [CrossRef] [PubMed]

16. Schmelzer, C.E.; Nagel, M.B.; Dziomba, S.; Merkher, Y.; Sivan, S.S.; Heinz, A. Prolyl hydroxylation in elastin is not random. Biochim. Biophys. Acta 2016, 1860, 2169-2177. [CrossRef] [PubMed]

17. Qi, H.H.; Ongusaha, P.P.; Myllyharju, J.; Cheng, D.; Pakkanen, O.; Shi, Y.; Lee, S.W.; Peng, J.; Shi, Y. Prolyl 4-hydroxylation regulates Argonaute 2 stability. Nature 2008, 455, 421-424. [CrossRef]

18. Kaelin, W.G., Jr.; Ratcliffe, P.J. Oxygen sensing by metazoans: The central role of the HIF hydroxylase pathway. Mol. Cell 2008, 30, 393-402. [CrossRef]

19. Ivan, M.; Kondo, K.; Yang, H.; Kim, W.; Valiando, J.; Ohh, M.; Salic, A.; Asara, J.M.; Lane, W.S.; Kaelin, W.G., Jr. HIFalpha targeted for VHL-mediated destruction by proline hydroxylation: Implications for O2 sensing. Science 2001, 292, 464-468. [CrossRef]

20. Gjaltema, R.A.; Bank, R.A. Molecular insights into prolyl and lysyl hydroxylation of fibrillar collagens in health and disease. Crit. Rev. Biochem. Mol. Biol. 2017, 52, 74-95. [CrossRef]

21. Kajihara, D.; Hon, C.C.; Abdullah, A.N.; Wosniak, J., Jr.; Moretti, A.I.S.; Poloni, J.F.; Bonatto, D.; Hashimoto, K.; Carninci, P.; Laurindo, F.R.M. Analysis of splice variants of the human protein disulfide isomerase (P4HB) gene. BMC Genom. 2020, 21, 766. [CrossRef] [PubMed]

22. Soares Moretti, A.I.; Martins Laurindo, F.R. Protein disulfide isomerases: Redox connections in and out of the endoplasmic reticulum. Arch. Biochem. Biophys. 2017, 617, 106-119. [CrossRef] [PubMed]

23. Hudson, D.M.; Eyre, D.R. Collagen prolyl 3-hydroxylation: A major role for a minor post-translational modification? Connect. Tissue. Res. 2013, 54, 245-251. [CrossRef] [PubMed]

24. Zimmerman, S.M.; Besio, R.; Heard-Lipsmeyer, M.E.; Dimori, M.; Castagnola, P.; Swain, F.L.; Gaddy, D.; Diekman, A.B.; Morello, R. Expression characterization and functional implication of the collagen-modifying Leprecan proteins in mouse gonadal tissue and mature sperm. AIMS Genet. 2018, 5, 24-40. [CrossRef] [PubMed]

25. Besio, R.; Garibaldi, N.; Leoni, L.; Cipolla, L.; Sabbioneda, S.; Biggiogera, M.; Mottes, M.; Aglan, M.; Otaify, G.A.; Temtamy, S.A.; et al. Cellular stress due to impairment of collagen prolyl hydroxylation complex is rescued by the chaperone 4-phenylbutyrate. Dis. Model. Mech. 2019, 12, dmm038521. [CrossRef]

26. Berra, E.; Benizri, E.; Ginouvès, A.; Volmat, V.; Roux, D.; Pouysségur, J. HIF prolyl-hydroxylase 2 is the key oxygen sensor setting low steady-state levels of HIF-1alpha in normoxia. EMBO J. 2003, 22, 4082-4090. [CrossRef]

27. Guo, J.; Chakraborty, A.A.; Liu, P.; Gan, W.; Zheng, X.; Inuzuka, H.; Wang, B.; Zhang, J.; Zhang, L.; Yuan, M.; et al. pVHL suppresses kinase activity of Akt in a proline-hydroxylation-dependent manner. Science 2016, 353, 929-932. [CrossRef]

28. Lee, S.B.; Ko, A.; Oh, Y.T.; Shi, P.; D’Angelo, F.; Frangaj, B.; Koller, A.; Chen, E.I.; Cardozo, T.; Iavarone, A.; et al. Proline Hydroxylation Primes Protein Kinases for Autophosphorylation and Activation. Mol. Cell 2020, 79, 376-389. [CrossRef]

29. Wilson, J.W.; Shakir, D.; Batie, M.; Frost, M.; Rocha, S. Oxygen-sensing mechanisms in cells. FEBS J. 2020, 287, 3888-3906. [CrossRef]

30. Strowitzki, M.J.; Cummins, E.P.; Taylor, C.T. Protein Hydroxylation by Hypoxia-Inducible Factor (HIF) Hydroxylases: Unique or Ubiquitous? Cells 2019, 8, 384. [CrossRef] [PubMed]

31. Ricard-Blum, S. The collagen family. Cold Spring Harb. Perspect Biol. 2011, 3, a004978. [CrossRef] [PubMed]

32. Brodsky, B.; Thiagarajan, G.; Madhan, B.; Kar, K. Triple-helical peptides: An approach to collagen conformation, stability, and self-association. Biopolymers 2008, 89, 345-353. [CrossRef]

33. Bella, J.; Brodsky, B.; Berman, H.M. Hydration structure of a collagen peptide. Structure 1995, 3, 893-906. [CrossRef]

34. Vitagliano, L.; Berisio, R.; Mazzarella, L.; Zagari, A. Structural bases of collagen stabilization induced by Pro hydroxylation. Biopolymers 2001, 58, 459-464. [CrossRef]

35. Taga, Y.; Tanaka, K.; Hattori, S.; Mizuno, K. In-depth correlation analysis demonstrates that 4-hydroxyproline at the Yaa position of Gly-Xaa-Yaa repeats dominantly stabilizes collagen triple helix. Matrix. Biol. Plus 2021, 10, 100067. [CrossRef]

36. Hamaia, S.; Farndale, R.W. Integrin recognition motifs in the human collagens. Adv. Exp. Med. Biol. 2014, 819, 127-142.

37. Chen, E.A.; Lin, Y.S. Using synthetic peptides and recombinant collagen to understand DDR-collagen interactions. Biochim. Biophys. Acta. Mol. Cell. Res. 2019, 1866, 118458. [CrossRef] [PubMed] 
38. Knight, C.G.; Morton, L.F.; Onley, D.J.; Peachey, A.R.; Ichinohe, T.; Okuma, M.; Farndale, R.W.; Barnes, M.J. Collagen-platelet interaction: Gly-Pro-Hyp is uniquely specific for platelet Gp VI and mediates platelet activation by collagen. Cardiovasc. Res. 1999, 41, 450-457. [CrossRef]

39. Montgomery, N.T.; Zientek, K.D.; Pokidysheva, E.N.; Bächinger, H.P. Post-translational modification of type IV collagen with 3-hydroxyproline affects its interactions with glycoprotein VI and nidogens 1 and 2. J. Biol. Chem. 2018, 293, 5987-5999. [CrossRef] [PubMed]

40. Lee, C.C.; Wu, C.Y.; Yang, H.Y. Discoveries of how cells sense oxygen win the 2019 Nobel Prize in Physiology or medicine. Biomed. J. 2020, 43, 434-437. [CrossRef]

41. Jaakkola, P.; Mole, D.R.; Tian, Y.M.; Wilson, M.I.; Gielbert, J.; Gaskell, S.J.; von Kriegsheim, A.; Hebestreit, H.F.; Mukherji, M.; Schofield, C.J.; et al. Targeting of HIF-alpha to the von Hippel-Lindau ubiquitylation complex by O2-regulated prolyl hydroxylation. Science 2001, 292, 468-472. [CrossRef]

42. Singh, A.K.; Carroll, K.; Perkovic, V.; Solomon, S.; Jha, V.; Johansen, K.L.; Lopes, R.D.; Macdougall, I.C.; Obrador, G.T.; Waikar, S.S.; et al. Daprodustat for the Treatment of Anemia in Patients Undergoing Dialysis. N. Engl. J. Med. 2021, 385, $2325-2335$. [CrossRef] [PubMed]

43. Laronha, H.; Caldeira, J. Structure and Function of Human Matrix Metalloproteinases. Cells 2020, 9, 1076. [CrossRef]

44. Eni-Aganga, I.; Lanaghan, Z.M.; Balasubramaniam, M.; Dash, C.; Pandhare, J. PROLIDASE: A Review from Discovery to its Role in Health and Disease. Front. Mol. Biosci. 2021, 8, 849. [CrossRef]

45. Visser, W.F.; Verhoeven-Duif, N.M.; de Koning, T.J. Identification of a human trans-3-hydroxy-L-proline dehydratase, the first characterized member of a novel family of proline racemase-like enzymes. J. Biol. Chem. 2012, 287, 21654-21662. [CrossRef]

46. Hallen, A.; Cooper, A.J.; Jamie, J.F.; Karuso, P. Insights into Enzyme Catalysis and Thyroid Hormone Regulation of Cerebral Ketimine Reductase/ $\mu$-Crystallin Under Physiological Conditions. Neurochem. Res. 2015, 40, 1252-1266. [CrossRef] [PubMed]

47. Adams, E.; Frank, L. Metabolism of proline and the hydroxyprolines. Annu. Rev. Biochem. 1980, 49, 1005-1061. [CrossRef]

48. Knight, J.; Jiang, J.; Assimos, D.G.; Holmes, R.P. Hydroxyproline ingestion and urinary oxalate and glycolate excretion. Kidney. Int. 2006, 70, 929-934. [CrossRef] [PubMed]

49. Summitt, C.B.; Johnson, L.C.; Jönsson, T.J.; Parsonage, D.; Holmes, R.P.; Lowther, W.T. Proline dehydrogenase 2 (PRODH2) is a hydroxyproline dehydrogenase (HYPDH) and molecular target for treating primary hyperoxaluria. Biochem. J. 2015, 466, 273-281. [CrossRef]

50. Hu, S.; He, W.; Wu, G. Hydroxyproline in animal metabolism, nutrition, and cell signaling. Amino Acids 2021. [CrossRef]

51. Monico, C.G.; Rossetti, S.; Belostotsky, R.; Cogal, A.G.; Herges, R.M.; Seide, B.M.; Olson, J.B.; Bergstrahl, E.J.; Williams, H.J.; Haley, W.E.; et al. Primary hyperoxaluria type III gene HOGA1 (formerly DHDPSL) as a possible risk factor for idiopathic calcium oxalate urolithiasis. Clin. J. Am. Soc. Nephrol. 2011, 6, 2289-2295. [CrossRef] [PubMed]

52. Belostotsky, R.; Pitt, J.J.; Frishberg, Y. Primary hyperoxaluria type III-A model for studying perturbations in glyoxylate metabolism. J. Mol. Med. 2012, 90, 1497-1504. [CrossRef] [PubMed]

53. Lismont, C.; Revenco, I.; Fransen, M. Peroxisomal Hydrogen Peroxide Metabolism and Signaling in Health and Disease. Int. J. Mol. Sci. 2019, 20, 3673. [CrossRef]

54. Birdsey, G.M.; Lewin, J.; Holbrook, J.D.; Simpson, V.R.; Cunningham, A.A.; Danpure, C.J. A comparative analysis of the evolutionary relationship between diet and enzyme targeting in bats, marsupials and other mammals. Proc. Biol. Sci. 2005, 272, 833-840. [CrossRef]

55. Ichiyama, A.; Xue, H.H.; Oda, T.; Uchida, C.; Sugiyama, T.; Maeda-Nakai, E.; Sato, K.; Nagai, E.; Watanabe, S.; Takayama, T. Oxalate synthesis in mammals: Properties and subcellular distribution of serine:pyruvate/alanine:glyoxylate aminotransferase in the liver. Mol. Urol. 2000, 4, 333-340. [PubMed]

56. Danpure, C.J. Variable peroxisomal and mitochondrial targeting of alanine: Glyoxylate aminotransferase in mammalian evolution and disease. Bioessays 1997, 19, 317-326. [CrossRef]

57. Liu, Y.; Xu, H.; Yuan, X.; Rossiter, S.J.; Zhang, S. Multiple adaptive losses of alanine-glyoxylate aminotransferase mitochondrial targeting in fruit-eating bats. Mol. Biol. Evol. 2012, 29, 1507-1511. [CrossRef]

58. Holbrook, J.D.; Birdsey, G.M.; Yang, Z.; Bruford, M.W.; Danpure, C.J. Molecular adaptation of alanine:glyoxylate aminotransferase targeting in primates. Mol. Biol. Evol. 2000, 17, 387-400. [CrossRef] [PubMed]

59. Wang, B.J.; Xia, J.M.; Wang, Q.; Yu, J.L.; Song, Z.; Zhao, H. Diet and Adaptive Evolution of Alanine-Glyoxylate Aminotransferase Mitochondrial Targeting in Birds. Mol. Biol. Evol. 2020, 37, 786-798. [CrossRef] [PubMed]

60. Ichiyama, A. Studies on a unique organelle localization of a liver enzyme, serine:pyruvate (or alanine:glyoxylate) aminotransferase. Proc. Jpn. Acad. Ser. B Phys. Biol. Sci. 2011, 87, 274-286. [CrossRef]

61. Adeva-Andany, M.; López-Ojén, M.; Funcasta-Calderón, R.; Ameneiros-Rodríguez, E.; Donapetry-García, C.; Vila-Altesor, M.; Rodríguez-Seijas, J. Comprehensive review on lactate metabolism in human health. Mitochondrion 2014, 17, 76-100. [CrossRef] [PubMed]

62. Iepsen, U.W.; Plovsing, R.R.; Tjelle, K.; Foss, N.B.; Meyhoff, C.S.; Ryrsø, C.K.; Berg, R.M.G.; Secher, N.H. The role of lactate in sepsis and COVID-19: Perspective from contracting skeletal muscle metabolism. Exp. Physiol. 2021, 31. [CrossRef] [PubMed]

63. Riedel, T.J.; Knight, J.; Murray, M.S.; Milliner, D.S.; Holmes, R.P.; Lowther, W. T: 4-Hydroxy-2-oxoglutarate aldolase inactivity in primary hyperoxaluria type 3 and glyoxylate reductase inhibition. Biochim. Biophys. Acta 2012, 1822, 1544-1552. [CrossRef] [PubMed] 
64. Huang, A.; Burke, J.; Bunker, R.D.; Mok, Y.F.; Griffin, M.D.; Baker, E.N.; Loomes, K.M. Regulation of human 4-hydroxy-2oxoglutarate aldolase by pyruvate and $\alpha$-ketoglutarate: Implications for primary hyperoxaluria type-3. Biochem. J. 2019, 476, 3369-3383. [CrossRef] [PubMed]

65. Pelkonen, R.; Kivirikko, K.I. Hydroxyprolinemia: An apparently harmless familial metabolic disorder. N. Engl. J. Med. 1970, 283, 451-456. [CrossRef] [PubMed]

66. Staufner, C.; Haack, T.B.; Feyh, P.; Gramer, G.; Raga, D.E.; Terrile, C.; Sauer, S.; Okun, J.G.; Fang-Hoffmann, J.; Mayatepek, E.; et al. Genetic cause and prevalence of hydroxyprolinemia. J. Inherit. Metab. Dis. 2016, 39, 625-632. [CrossRef] [PubMed]

67. Frishberg, Y.; Zeharia, A.; Lyakhovetsky, R.; Bargal, R.; Belostotsky, R. Mutations in HAO1 encoding glycolate oxidase cause isolated glycolic aciduria. J. Med. Genet. 2014, 51, 526-529. [CrossRef] [PubMed]

68. McGregor, T.L.; Hunt, K.A.; Yee, E.; Mason, D.; Nioi, P.; Ticau, S.; Pelosi, M.; Loken, P.R.; Finer, S.; Lawlor, D.A.; et al. Characterising a healthy adult with a rare HAO1 knockout to support a therapeutic strategy for primary hyperoxaluria. eLife 2020, 9, e54363. [CrossRef] [PubMed]

69. Hoyer-Kuhn, H.; Kohbrok, S.; Volland, R.; Franklin, J.; Hero, B.; Beck, B.B.; Hoppe, B. Vitamin B6 in primary hyperoxaluria I: First prospective trial after 40 years of practice. Clin. J. Am. Soc. Nephrol. 2014, 9, 468-477. [CrossRef]

70. Lorenz, E.C.; Lieske, J.C.; Seide, B.M.; Olson, J.B.; Mehta, R.; Milliner, D.S. Recovery From Dialysis in Patients With Primary Hyperoxaluria Type 1 Treated With Pyridoxine: A Report of 3 Cases. Am. J. Kidney Dis. 2021, 77, 816-819. [CrossRef]

71. Forbes, T.A.; Brown, B.D.; Lai, C. Therapeutic RNA interference: A novel approach to the treatment of primary hyperoxaluria. Br. J. Clin. Pharmacol. 2021. [CrossRef] [PubMed]

72. Moya-Garzon, M.D.; Gomez-Vidal, J.A.; Alejo-Armijo, A.; Altarejos, J.; Rodriguez-Madoz, J.R.; Fernandes, M.X.; Salido, E.; Salido, S.; Diaz-Gavilan, M. Small Molecule-Based Enzyme Inhibitors in the Treatment of Primary Hyperoxalurias. J. Pers. Med. 2021, 11, 74. [CrossRef] [PubMed]

73. Weigert, A.; Martin-Higueras, C.; Hoppe, B. Novel therapeutic approaches in primary hyperoxaluria. Expert. Opin. Emerg. Drugs. 2018, 23, 349-357. [CrossRef] [PubMed]

74. Titze-de-Almeida, R.; David, C.; Titze-de-Almeida, S.S. The Race of 10 Synthetic RNAi-Based Drugs to the Pharmaceutical Market. Pharm. Res. 2017, 34, 1339-1363. [CrossRef] [PubMed]

75. Scott, L.J.; Keam, S.J. Lumasiran: First Approval. Drugs 2021, 81, 277-282. [CrossRef]

76. Ariceta, G.; Barrios, K.; Brown, B.D.; Hoppe, B.; Rosskamp, R.; Langman, C.B. Hepatic Lactate Dehydrogenase A: An RNA Interference Target for the Treatment of All Known Types of Primary Hyperoxaluria. Kidney Int. Rep. 2021, 6, 1088-1098. [CrossRef]

77. Lai, C.; Pursell, N.; Gierut, J.; Saxena, U.; Zhou, W.; Dills, M.; Diwanji, R.; Dutta, C.; Koser, M.; Nazef, N.; et al. Specific Inhibition of Hepatic Lactate Dehydrogenase Reduces Oxalate Production in Mouse Models of Primary Hyperoxaluria. Mol. Ther. 2018, 26, 1983-1995. [CrossRef]

78. Hoppe, B.; Koch, A.; Cochat, P.; Garrelfs, S.F.; Baum, M.A.; Groothoff, J.W.; Lipkin, G.; Coenen, M.; Schalk, G.; Amrite, A.; et al. Safety, pharmacodynamics, and exposure-response modeling results from a first in human phase 1 study of nedosiran in primary hyperoxaluria. Kidney Int. 2021. [CrossRef]

79. Shee, K.; Ahn, J.; Hamouche, F.; Mena, J.; Chi, T.; Stoller, M.L. Nedosiran Dramatically Reduces Serum Oxalate in DialysisDependent Primary Hyperoxaluria 1: A Compassionate Use Case Report. Urology 2021, 156, e147-e149. [CrossRef]

80. Baum, M.A.; Langman, C.B.; Cochat, P.; Lieske, J.; Moochhala, S.; Hamamoto, S.; Satoh, H.; Mourani, C.; Ariceta, G.; Amrite, A.; et al. PHYOX2: Nedosiran reduced urinary oxalate excretion in patients with primary hyperoxaluria. J. Am. Soc. Nephrol. 2021, 32. Available online: https:/ / www.asn-online.org/education/kidneyweek/2021/program-abstract.aspx?controlId=3627285 (accessed on 21 December 2021).

81. Dicerna Pharmaceuticals, Press Release 19 October 2021. Available online: https://investors.dicerna.com/news-releases/newsrelease-details / dicerna-announces-results-phyoxtm4-single-dose-study-nedosiran (accessed on 21 December 2021). 